\title{
ANIMASI DENGAN GAMBAR BERGERAK MENINGKATKAN DAYA TARIK PROGRAM PROMOSI
}

\author{
Dewi Immaniar Desrianti ${ }^{1}$ \\ Ahmad Nur Firdaus ${ }^{2}$ \\ Deny Pangestu Gunawan ${ }^{3}$ \\ Pasca Sarjana Magister Teknik Informatika STMIK Raharja ${ }^{1}$, \\ STMIK Raharja Jurusan Teknik Informatika², \\ STMIK Raharja Jurusan Teknik Informatika ${ }^{3}$ \\ Email :dewi.immaniar@raharja.info,ahmadnurfirdaus@raharja.info,denypangestu@raharja.info
}

Diterima: 8 Desember 2016/ Disetujui : 22 Desember 2016

\begin{abstract}
The development of creative industries is growing, as evidenced by the many industry-emerging creative industry. The media campaign is currently very helpful in supporting the information and communication All of that is because of the many interests of the creative industry services. Many competitors require companies to do promotions to attract customers. Penyajiaan media ads interesting and entertaining will encourage the general public to find out more detail and have an interest to join a company or institute of technology is so rapid in PT.Movio Screen as a company engaged in the creative industry. Have a good portfolio will make promotion and enhance the corporate image. $3 D$ animation movie series is a very good portfolio and attractive for media promotion for a company in the field of creative industries, in addition to the $3 D$ animated film can enhance a company's image. In the $3 D$ animation movie of the series can also be a support to increase the creation of the nation of the $3 D$ animated film, to be more creative again in making animated films in $3 D$ and can inspire people to work in the creative industries in order to generate industry local animation, based on a story in this animation.
\end{abstract}

Keywords: Promotion, 3D animated film series.

\begin{abstract}
ABSTRAK
Perkembangan dunia industri kreatif semakin berkembang, terbukti dengan banyaknya industryindustry kreatif yang bermunculan. Media promosi saat ini sangat membantu dalam menunjang informasi dan komunikasi Semua itu dikarenakan banyaknya minat terhadap jasa industri kreatif . Banyaknya pesaing mengharuskan perusahaan untuk melakukan promosi untuk menarik minat konsumen. Penyajiaan media iklan yang menarik dan menghibur akan mendorong masyarakat luas untuk mengetahui lebih detail dan memiliki minat untuk bergabung dalam suatu perusahaan atau lembaga teknologi yang begitu pesat pada PT.Movio Screen sebagai perusahaan yang bergerak dibidang industry creative. Memiliki portofolio yang baik akan menjadikan sarana promosi dan meningkatkan citra perusahaan. Film Animasi 3D serial adalah portofolio yang sangat baik dan menarik untuk media promosi bagi sebuah perusahaan dalam bidang industry kreatif, selain itu film animasi 3D dapat meningkatkan citra sebuah perusahaan. Dalam film animasi 3D serial ini juga dapat menjadi penunjang untuk meningkatkan kreasi anak bangsa terhadap film animasi 3D , supaya lebih berkreasi lagi dalam membuat film animasi 3D dan dapat menginspirasikan orang banyak untuk berkarya dalam industry kreatif supaya dapat membangkitkan industry animasi lokal, berdasarkan cerita dalam animasi ini.
\end{abstract}

Kata kunci : Promosi, film animasi 3D serial 


\section{PENDAHULUAN}

Perkembangan animasi 3 Dimensi (3D) di Indonesia saat ini sudah mulai maju, ada beberapa animasianimasi serial dan iklan yang bermunculan di TV. Sulitnya dalam proses pembuatan animasi 3D khususnya untuk animasi bergerak membutuhkan waktu yang lama. Sehingga banyak diantara animasi-animasi yang tayang di TV memiliki kekurangan, seperti kurang baiknya pergerakan pada karakter.

Perkembangan perusahaan dibidang advertising saat ini meningkat pesat untuk itu persaingan menjadi semakin ketat. Untuk menjaring customer dan relasi yang banyak maka dibutuhkan suatu kreatifitas hingga membuat customer dan relasi berminat memakai jasa perusahaan. Film animasi serial 3D dirasa dapat menjadi portofolio yang dapat meningkatkan citra dan image perusahaan dan dapat menjadi sarana promosi yang baik bagi PT. Movio Screen sehingga dapat menarik klien dan konsumen yang lebih luas.

Serial Animasi 3D dianggap dapat meningkatkan promosi, dengan berbasis film serial 3D dengan tokoh character yang di sukai oleh masyarakat diperankan oleh dua karakter pic dan ito, yang menceritakan mengenai persahabatan dengan mengenalkan permainan tradisional untuk mengangkat kembali budaya Indonesia sehingga diharapkan serial animasi ini mempunyai ciri khas tersendiri, serial animasi ini berdurasi kurang lebih 4 menit.

PT.Movio Screen adalah perusahaan yang bergerak pada bidang industri kreatif yang memproduksi info graphic $2 \mathrm{~d} / 3 \mathrm{~d}$, life action, $3 d$ development, augment reality, dan public service announcement, Hingga saat ini PT. Movio Screen belum memiliki sebuah portofolio yang berupa film animasi serial berbasis $3 \mathrm{D}$.

\section{PERMASALAHAN}

Dalam kasus ini, pentingnya media promosi dengan design karakter animasi 3d untuk dapat perhatian sebagai sarana promosi sehingga relasi dan calon konsumen lebih mengenal dan menjadi pelanggan pada PT. Movio Screen . Dikarenakan ketatnya persaingan di bidang perusahaan desain animasi grafis , maka dari itu dalam pembahasan ini akan membahas tentang pembuatan film animasi 3D serial sebagai sarana promosi pada PT. Movio Screen . Pergerakan dalam bidang animasi di Indonesia masih belum baik disebabkan kurangnya minat masyarakat dalam bidang animasi, dan minimnya pelatihan mengenai animasi gerak.

\section{PEMECAHAN MASALAH}

Untuk menyelesaikan permasalahan di atas, maka diperlukan media promosi yang tepat. Saat ini media promosi menggunakan animasi 3D terbilang sedikit, maka dari itu dibuatlah media promosi yang berbeda, yaitu menggunakan animasi 3D. Serta animasi 3D ini diharapkan membuat masyarakat mengetahui perkembangan animasi 3D di Indonesia.

\section{TINJAUAN PUSTAKA}

\section{Prinsip animasi}

Menurut International Design School [5] ada 12 prinsip animasi yang di adopsi dari animasi Walt Disney.

1. Solid Drawing adalah Dasar utama tentang animasi adalah menggambar, meskipun saat ini sudah ada komputer namun menggambar secara manual dianggap menghasilkan animasi yang lebih berkualitas.. Menggambar memiliki peranan bagi sebuah animasi, khususnya animasi klasik ditinjau dari proses ataupun hasilnya. Menggambar bisa menjadi sebuah observasi dalam pemahaman terhadap anatomi, komposisi, berat, keseimbangan, dan pencahayaan. Dari gambar 1 di bawah dapat dilihat Solid Drawing untuk karakter mickey mouse, disini dasar dari pembuatan gambar yang lebih kelihatan hidup. 

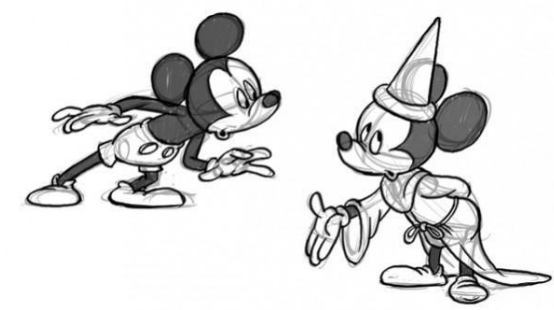

Gambar 1. Solid Drawing

sumber: http://bbsimg.ngfiles.com/14/19197000/ngbbs4a15a55a700dd.jpg

2. Timing \& Spacing adalah Animator Disney, Grim Natwick, mengatakan, "Animasi adalah tentang timing dan spacing" Timing yaitu ketika animator menentukan waktu kapan sebuah gerakan harus dilakukan. Spacing yaitu menentukan percepatan dan perlambatan dari bermacammacam gerak. Pada gambar 2 dibawah ini memperlihatkan gerakan yang sudah di atur kecepatan dan geraknya .

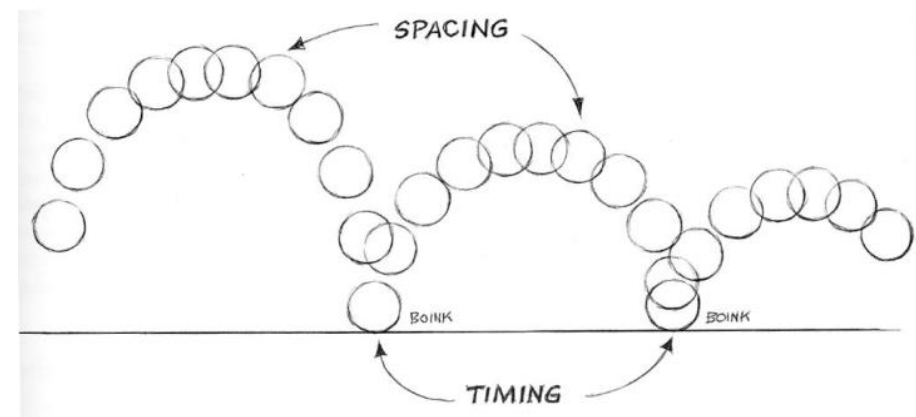

Gambar 2. Timing and Spacing

sumber: http://profspevack.com/archive/animation/tech_support/images/spacingtiming.jpg

3. Squash \& Stretch adalah Prinsip animasi yang satu ini mengupayakan efek lentur pada karakter seolah-olah memuai dan menyusut sehingga memberikan efek yang lebih hidup. Contoh paling mudah adalah kamu bayangkan sebuah bola dilemparkan. Saat menyentuh tanah, maka bola yang awalnya bulat menjadi lonjong horizontal, hal ini memberikan efek yang dinamis dan lebih hidup. Pada gambar 3. Di bawah ini memperlihatkan efek lentur yang memberikan efek lebih hidup dan lebih nyata .

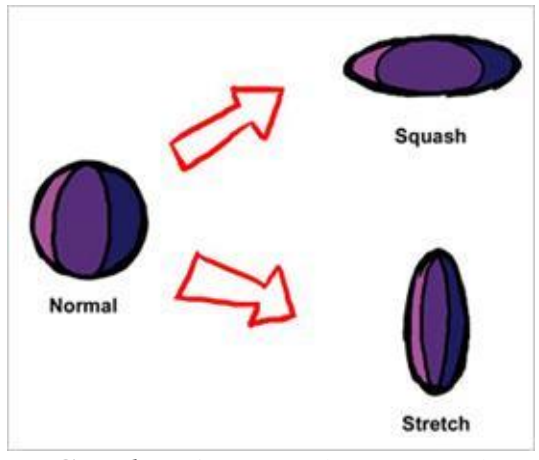

Gambar 3. Squash \& Stretch

sumber: https://genchevblog.files.wordpress.com/2011/12/tips_squashstretch-02-1.jpg

4. Prinsip Anticipation bisa dikatakan sebagai persiapan gerak atau ancang-ancang. Misalnya saat sebuah karakter yang ingin melompat, karakter tersebut harus memiliki gerakan membungkuk terlebih dahulu kemudian baru benar-benar melompat. Pada gambar 4 di bawah ini memperlihatkan gerakan ancang-ancang saat ingin melempar bola dan gerakan antisipasi pada saat ingin mengambil bola. 


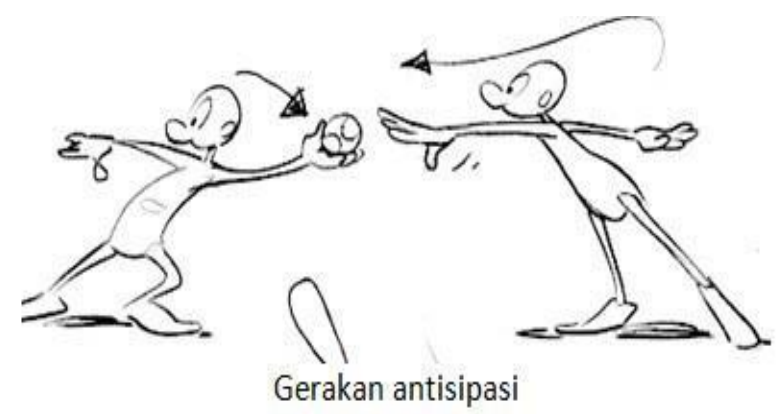

Gambar 4. Anticipation

sumber: https://dodyandanimation.files.wordpress.com/2011/03/27-03-2011-5-52-31.jpg

5. Slow In \& Slow Out adalah Prinsip animasi Slow In \& Slow Out menegaskan bahwa setiap gerakan memiliki kecepatan dan kelambatan yang berbeda.

6. Arcs adalah Sistem pergerakan karakter yang ada biasanya bergerak mengikuti pola atau dikenal dengan Arcs.

7. Secondary Action adalah dibuat untuk memperkuat gerakan pertama agar terlihat lebih realistis. Pada gambar 5 di bawah ini memperlihatkan gerakan-gerakan yang lebih realistis di setiap gerakannya.

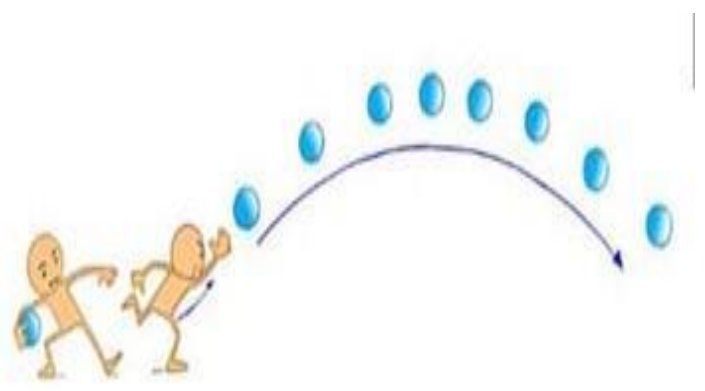

Gambar 5 Secondary Action

8. Follow Through \& Overlapping Action, Follow through bisa digunakan untuk membuat bagian tubuh tertentu tetap bergerak meskipun sebuah karakter berhenti bergerak. Overlapping action secara mudah bisa dianggap sebagai gerakan saling-silang. Maksudnya, adalah serangkaian gerakan yang saling mendahului (overlapping). Pergerakan tangan dan kaki ketika berjalan bisa termasuk didalamnya.

9. Straight Ahead \& Pose to pose Ada dua cara yang bisa dilakukan animator dalam membuat animasi, yaitu straight ahead action dan pose to pose.

10. Staging Prinsip animasi staging meliputi bagaimana lingkungan dibuat untuk mendukung suasana atau 'mood' yang ingin dicapai dalam sebagian atau keseluruhan scene. Pada gambar 4 terlihat staging dengan ekspresi yang berbeda dengan mengikuti scene yang sudah di tentukan

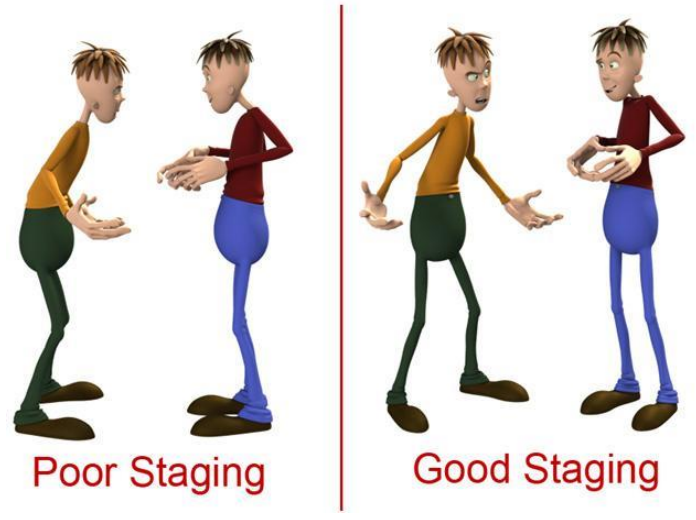

Gambar 6. Staging

sumber: https://ailytanza.files.wordpress.com/2013/04/8.jpg 
11. Appeal Setiap animasi atau studio animasi memiliki gaya visualnya masing-masing. Misalnya saja kamu bisa membedakan gaya animasi buatan Jepang, Disney, atau Dreamworks walaupun melihat dengan sekilas.

12. Exaggeration Kamu mungkin sudah sangat sadar bahwa film animasi kebanyakan dibuat secara berlebihan atau hiperbolis.

\section{Pengertian Media}

Menurut Dewi Immaniar Desrianti dkk, dalam journal CCIT [3]. Media adalah segala bentuk yang digunakan untuk menyalurkan informasi. Pengertian media yang diberikan AECT (Association for education communication and tecnology) ini menunjukkan bahwa istilah "media" memiliki makna yang sangat umum.

\section{Pengertian portofolio}

Menurut Zaenal arifin [2] Secara umum, portofolio merupakan kumpulan dokumen berupa objek penilaian yang dipakai oleh seseorang, kelompok, lembaga, organisasi, atau perusahaan yang bertujuan untuk mendokumentasikan dan menilai perkembangan suatu proses.

\section{Pengertian Animasi}

Menurut International Design School.[5]. Animasi adalah gambar begerak berbentuk dari sekumpulan objek (gambar) yang disusun secara beraturan mengikuti alur pergerakan yang telah ditentukan pada setiap pertambahan hitungan waktu yang terjadi.

\section{LITERATURE REVIEW}

penulis melakukan literature review terhadap penelitian-penelitian sebelumnya sebagai berikut:

1. Penelitian yang di lakukan oleh Jostonchoniv, Yudhi Windarto pada tahun 2013 dengan judul "PEMBUATAN FILM ANIMASI 3D CERITA RAKYAT "THE LEGEND OF TOBA LAKE" Film animasi adalah jenis film yang banyak digemari oleh berbagai kalangan, dikarenakan film animasi mengandung visualisasi yang unik dan sangat menarik. Di dalam film animasi seorang sutradara dapat menampilkan skenario yang tidak mungkin diperagakan oleh manusia. Nilai nilai moral dan budaya bangsa menjadi suatu hal yang dapat dimasukkan dalam sebuah film animasi. Cerita - cerita rakyat menjadi aset budaya bangsa yang harus dilestarikan. Untuk memenuhi hal tersebut, maka dibuat sebuah film animasi dengan judul "The Legend of Toba Lake". Pembuatan film animasi 3D ini dirancang dengan menggunakan software Blender 2.63.

2. Penelitian yang di lakukan oleh Hendro Saputra Suratinoyo, Hans Wowor, Jimmy Robot, Stanley Karouw pada tahun 2013 dengan judul "CERITA RAKYAT DAERAH MINAHASA : IMPLEMENTASI SHORT FILM ANIMASI 3D” Hendro Saputra Suratinoyo, Hans Wowor, Jimmy Robot, Stanley Karouw. Multimedia bukan hanya menyediakan banyak teks, melainkan juga dengan menghidupkan teks yang di sertai bunyi, gambar, musik, Animasi dan video. Cerita rakyat daerah minahasa : Implementasi short film animasi 3D, didasarkan pada ide dan alur cerita yang mendukung kegiatan produksi film animasi 3D, produksi film animasi 3D menggunakan kerangka penelitian film pendek animasi 3D. Software yang digunakan: blender, audacity, avidemux. Objek-objek yang telah selesai dibuat akan ditata sesuai kebutuhan adegan, animasi dilakukan dengan proses rigging serta skinning pada objek karakter. Animasi yang telah dibuat akan dirender, render berupa potongan-potongan adegan dalam bentuk video.Untuk jalannya audio disesuaikan dengan jalannya video. Setelah semua potongan - potongan adegan video sudah dilengkapi dengan audio. Penggabungan adegan - adegan video, menghasilkan keluaran video animasi 3D secara keseluruhan.

3. Penelitian yang di lakukan oleh Milania pada tahun 2010 yang berjudul "PEMBUATAN FILM ANIMASI 3 DIMENSI BERJUDUL “IMPIAN RAHMA" MENGGUNAKAN 3d STUDIO MAX 7.0". Perkembangan dunia animasi menjadi pusat perhatian dari berbagai kalangan. Mulai dari kalangan anak-anak, remaja dan orang dewasa. Hal ini semakin mendukung para pemilik 
industri terus memproduksi animasi untuk publik. Di Indonesia, perkembangan industri animasi masih relatif kecil jika dibandingkan dengan negara-negara besar seperti Jepang dan Amerika. Namun dalam hal sumber daya manusia, Indonesia memiliki banyak animator yang dapat diberdayakan untuk mengembangkan kerja animasi di Indonesia. Mengingat ini, untuk membantu para animator keberadaan di Indonesia, penulis mencoba untuk membuat karya animasi tiga dimensi menggunakan 3D Studio Max 7.0 Ruang lingkup pembuatan adalah dalam proses merancang untuk produksi.

4. Penelitian yang di lakukan oleh Cahya Budi Wibawa pada tahun 2011 yang berjudul "PEMBUATAN FILM ANIMASI 3D ANAK BERJUDUL "AYO KITA SHALAT" Menggunakan layanan multimedia saat ini bukanlah sesuatu aneh. Multimedia mampu menutupi kelemahan teknik presentasi yang umum digunakan, terutama dalam hal penyajian karya efek realistis obyek 3D .Multimedia memberikan arti baru pada dunia pendidikan dan sebagai sarana media pembelajaran yang efektif . Informasi dalam bentuk multimedia yang dapat diterima oleh kedua indera penglihatan dan pendengaran untuk membuat orang lebih tertarik untuk mendengarkan. Film ini mengisahkan tentang pentingnya doa ini berisi panggilan untuk salat, terutama untuk anak-anak dan remaja, lihat sekarang ini banyak anak yang meninggalkan kewajiban sholat untuk melakukan hal-hal yang tidak berguna, seperti bermain game online, menonton tv , bahkan perkelahian .Software untuk membuat film ini adalah Autodesk 3ds Max 2010, dengan software ini dapat menggabungkan berbagai elemen multimedia seperti teks 3D , animasi dan suara sehingga film ini akan menjadi lebih menarik

5. Penelitian yang di lakukan oleh Moh. Ali Anwar, Sugiyono Ardjaka, dan Joko Samodra pada tahun 2012 yang berjudul "PERANCANGAN FILM ANIMASI "BUDI" UNTUK MENANAMKAN BUDI PEKERTI KEPADA ANAK-ANAK" Film animasi digunakan sebagai tempat terjadinya proses pembentukan identitas diri anak, maksudnya adalah dalam kesehariannya anak-anak dimungkinkan akan meniru prilaku seperti tokoh kartun tersebut. Masa anak-anak merupakan titik awal perkembangan dan pertumbuhan manusia yang sangat penting. Pada masa kanak-kanak yaitu pada anak usia 6 sampai 9 tahun, mereka dapat melakukan berbagai tugas yang kongkrit sehingga mudah terpengaruh terhadap adanya media-media yang dapat berdampak negatif. Maka diperlukan suatu inovasi baru yang dapat menjadikan media hiburan juga sebagai media penyampaian pesan-pesan untuk menanamkan budi pekerti, yaitu dengan membuat film animasi 3 dimensi. Perancangan ini menggunakan metode prosedural yang bersifat deskriptif. Model yang digunakan dalam perancangan ini adalah Model perancangan $M$. Yoshioka. Selanjutnya dari model tersebut, dapat ditentukan sistematika perancangan film animasi dengan penyesuaian menurut Issac Kerlow dengan alur praproduksi, produksi, dan pascaproduksi. Teknik analisis yang digunakan adalah USP (Unique Selling Preposition) dengan menganalisa isi produk yang kemudian ditarik kesimpulan. Produk yang dihasilkan dalam perancangan ini adalah film animasi 3 dimensi yang berisi pesan-pesan moral yang positif dengan target audience anak pada usia kanak-kanak. Kesimpulan yang dapat ditarik dalam perancangan ini adalah film animasi 3 dimensi yang mengajarkan nilai-nilai positif masih jarang ditemukan dipasaran sehingga film ini menjadi pilihan alternatif yang baru bagi masyarakat. Dengan ilustrasi kartun animasi 3 dimensi serta model karakter yang realis dan cerita yang khas Indonesia akan menarik minat masyarakat, dan diharapkan mempermudah anak-anak lebih memahami isi cerita.

\section{PEMBAHASAN}
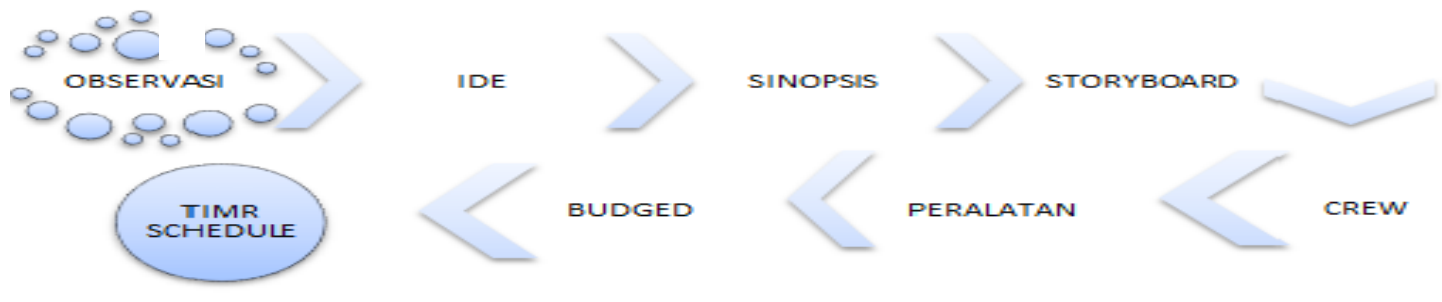

Gambar 7 . Preproduction 
Dalam pembahasan ini implementasi di jelaskan lebih lanjut untuk preproduction berupa ide , sinopsis, dan storyboard yang akan di jelaskan lebih lanjut

Ide

PT. Movio Screen inggin meningkatkan citra dan image kepada relasi, konsumen dan masyarakat luas sebagai perusahaan animasi 3D yang memiliki kualitas yang baik. Film animasi serial merupakan media yang sangat efektif untuk meningkatkan citra dan image serta menjadi media promosi dan portofolio yang lebih baik bagi PT. Movio Screen

\section{Sinopsis}

Dua tokoh karakter yang sedang duduk asik di sebuah halte sambil menikmati sate, mereka berdua adalah pic dan ito. Sedang asik asik nya menikmati kansate, jatuhlah sebuah sesuatu yang berkilau dan ternyata itu adalah sebuah bambu, mereka berdua kemudian saling menatap dan memiliki ide masing-masing kemudian mereka memperebutkan bambu tersebut. Ito dengan karakter jailnya ingin membuat pletokan untuk menebak pic, sedang pic dengan keluguanya inggin membuat suling untuk dimainkan. Ito dengan peletokanya menembakan ke arah pic, tapi tembakan tersebut meleset, sehingga ito mengupgrade senjatanya.setelah pic pun ikut membuat sebuah pletokan dan ito menembak kembali si pic ternyata meleset kembali, ito pun sangat marah kemudian senjatanya di upgrade ketingkat level yg lebih tinggi yaitu roket. Ito menembakkan kembali dan yang terjadi setelah roket di luncurkan pic dengan senangnya malah menaiki roket tersebut.setelah beberapa saat pic terjatuh dari roket dan pletokan yang di pegang oleh pic tidak sengaja menembak kearah ito dan mengenainya. Ito pun sangat murka kemudian ito mengupgrade ketingkat akhir yaitu machinegun dan mulai menembaki si pic, tetapi si pic bisa menghindari semua peluru-peluru tersebut.kemudian pic melihat ito yang sudah tidak bersemangat lagi, maka pic pun dengan sengaja mengarahkan tubuhnya kearah peluru, sehingga dia tertembak, ito pun kaget dikarenakan pic tertembak dan itopun merasa senang dan bersemangat kembali dan melempar-lemparkan pic ke udara dan akhirnya mereka berdua bersahabat kembali.

\section{Story Board}

Storyboard adalah sebuah gambar sket yang dilengkapi dengan petunjuk atau catatan pengambilan gambar sekaligus gerak pada sebuah charácter untuk kebutuhan pembuatan animasi. Selama proses praproduksi, perencanaan yang berhubungan dengan visualiasasi yang akan dibuat membutuhkan Storyboard sebagai media bantuannya.

SCENE I:

Menampilkan adegan pembukaan yang meriah, pada gambar 8. Dibawah ini memperlihatkan pembukaan yang sangat meriah yang berjudul ARARATEUL

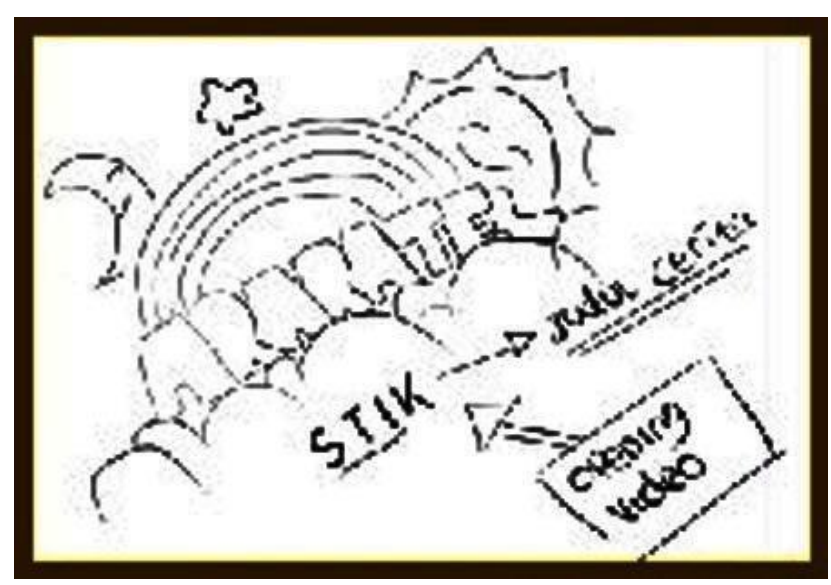

Gambar 8. adegan pembukaan 


\section{SCENE II:}

Menampilkan adegan kamera masuk dari atas awan, zoom in ke 2 character, pada gambar 9. Di bawah ini menampilkan 2 character yaitu pic dan ito yang mempunya character yang berbeda Ito memiliki character sangat jail dan Pic memiliki character yang sangat lugu

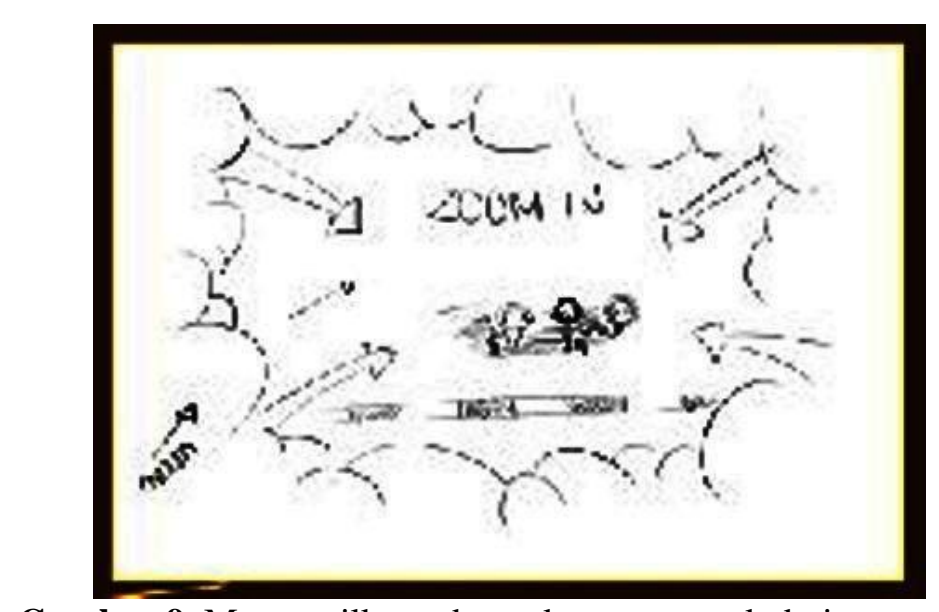

Gambar 9. Menampilkan adegan kamera masuk dari atas awan, zoom in ke 2 character

\section{SCENE III:}

Menampilkan adegan sedang menikmati sate, pada gambar 10. Dibawah ini terlihat Pic dan ito yang sedang duduk di halte dan menikmati sate

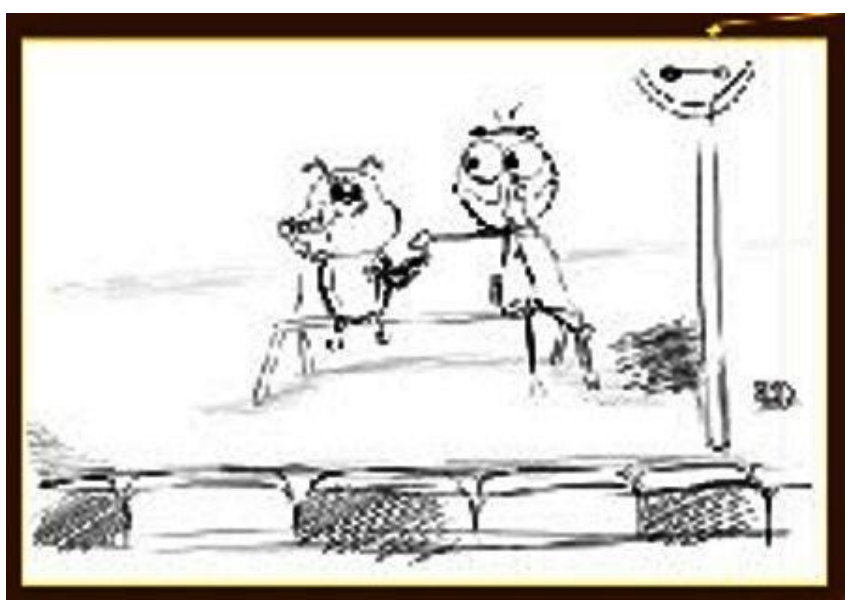

Gambar 10. Menampilkan adegan sedang menikmati sate

\section{Modelling}

\section{Rigging}

\section{Skinning}

\section{Animation}

\section{Hasil Rendering}

Gambar 11. Production 
Dalam gambar 11. Production memperlihatkan dalam pembuatan dalam animasi, untuk perancangan gerak animasi disini prinsip animasi gerak yang di pakai ada 7 yaitu :

\section{Solid Drawing}

Dasar utama tentang animasi adalah menggambar, Menggambar bisa menjadi sebuah observasi dalam pemahaman terhadap anatomi, komposisi, berat, keseimbangan, dan pencahayaan. Dalam project ini solid drawing yaitu character Pic dan Ito yang digambarkan sebagai berikut :

\section{Solid Drawing Ito}

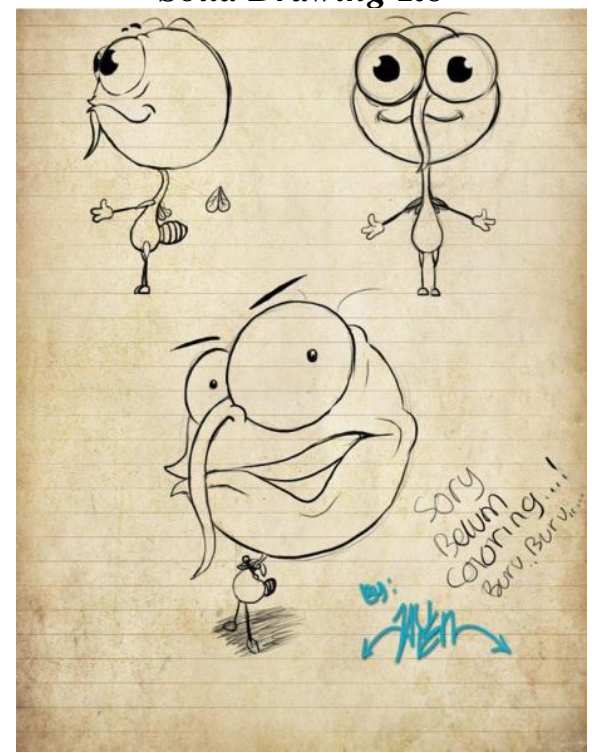

Gambar 12. Solid Drawing Ito,

Dasar pada saat pembuatan karakter Ito, dapat di lihat pada Gambar 12. Solid drawing pada ito terlihat gambar lebih hidup dan karakter ito mempunyai sifat jail dan sangat kreatif

\section{Solid Drawing pic}

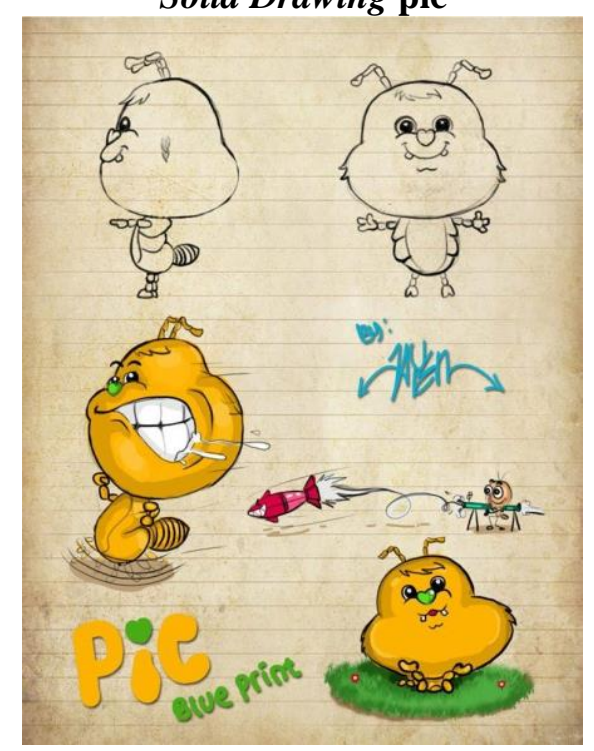

Gambar 13 Solid Drawing Pic

Dasar pada pembuatan karakter Pic , dapat di lihat pada gambar 13. Solid Drawing Pada Pic terlihat lebih nyata karna efek pewarnaan dan karakter Pic mempunyai sifat lugu dan sangat kreatif 


\section{Animation}

Animasi adalah proses pergerakan sebuah character dimana suatu pemahaman tentang cara bergerak objek adalah sangat penting untuk menjadi seorang animator. Dalam pergeraka character yang baik yaitu pergerakan yang natural atau pergerakan yang real maka dalam animation character digunakanlah beberapa prinsip animasi seperti berikut:

\section{Timing \& Spacing}

Timing yaitu ketika animator menentukan waktu kapan sebuah gerakan harus dilakukan. Spacing yaitu menentukan percepatan dan perlambatan dari bermacam-macam gerak.

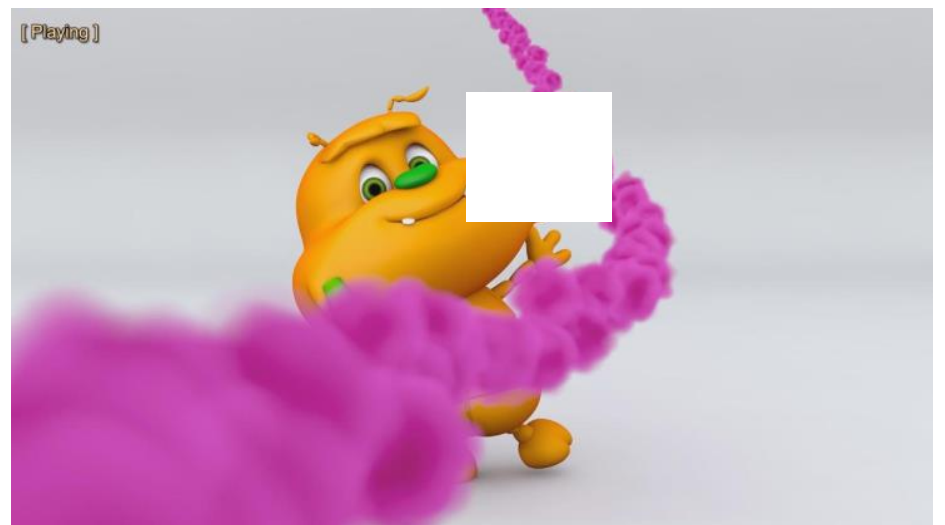

Gambar 14. Timing \& Spacing pada adegan Pic menghindar dari roket

Pada gambar 14. Terlihat Pic yang sedang menghindar dari roket yang di tembakan oleh ito, tetapi roket yang di tembakan oleh ito selalu meleset, ito kesal karna roket yang di tembakan kepada pic selalu meleset .

\section{Squash \& Stretch}

Squash \& Stretch adalah prinsip Animasi untuk mengupayakan efek lentur pada karakter seolah-olah memuai dan menyusut sehingga memberikan efek yang lebih hidup.

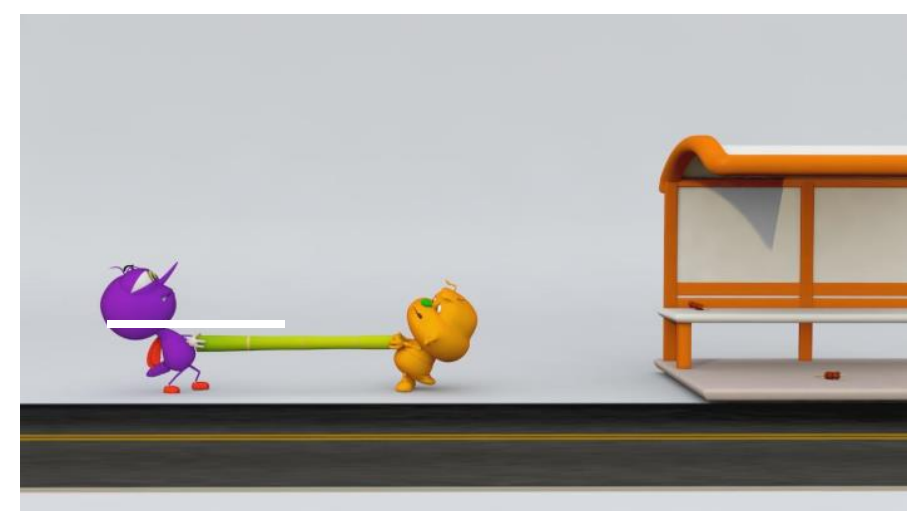

Gambar 15 Squash \& Stretch pada bagian bambu

Pada gambar 15. Terlihat Ito dan Pic memperebutkan bambu tersebut. Ito dengan karakter jailnya ingin membuat pletokan untuk menebak pic, sedang pic dengan keluguanya ingin membuat suling untuk dimainkan. Ito dengan peletokanya menembakkan ke arah pic, tapi tembakan tersebut meleset, sehingga ito mengupgrade senjatanya.setelah pic pun ikut membuat sebuah pletokan dan ito menembak kembali si pic ternyata meleset kembali, ito pun sangat marah kemudian senjatanya di upgrade ketingkat level yg lebih tinggi yaitu roket.

\section{Anticipation}

Prinsip Anticipation bisa dikatakan sebagai persiapan gerak atau ancang-ancang sebelum gerakan utama. 


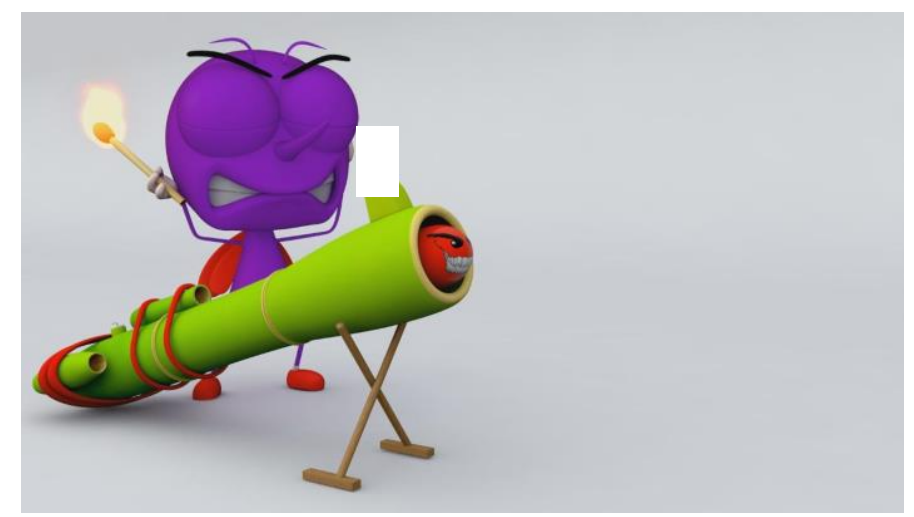

Gambar 16. Anticipation saat roket ingin keluar

Pada gambar 16. Terlihat Ito dengan ekspresi kesal sedang mengambil ancang - ancang untuk meluncurkan roketnya ke arah Pic . Pic dengan senangnya malah menaiki roket tersebut.setelah beberapa saat pic terjatuh dari roket dan pletokan yang di pegang oleh pic tidak sengaja menembak kearah ito dan mengenainya. Ito pun sangat murka.

\section{Slow In \& Slow Out}

Prinsip animasi Slow In \& Slow Out menegaskan bahwa setiap gerakan memiliki kecepatan dan kelambatan yang berbeda

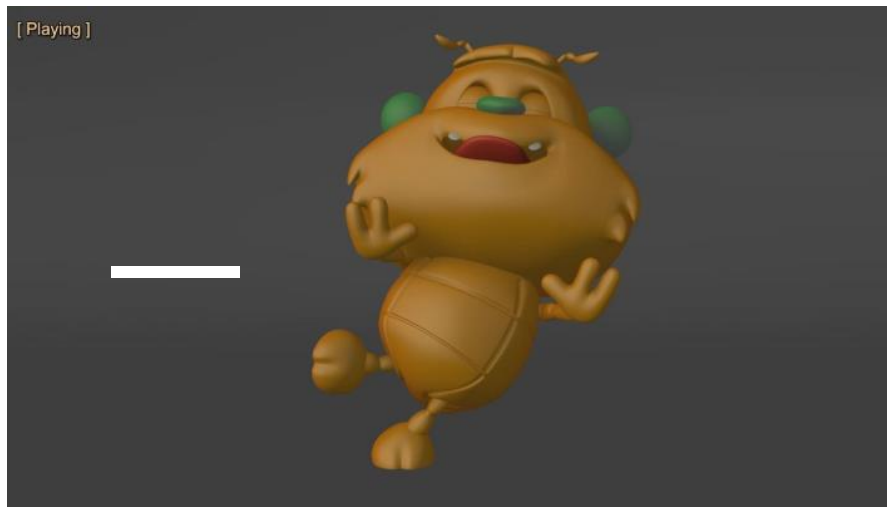

Gambar 17. Slow In \& Slow Out pada saat Pic menghindar dari peluru

Pada gambar 17. Terlihat Pic bisa menghindari semua peluru-peluru yang di di tembakkan oleh Ito kemudian Pic melihat ito yang sudah tidak bersemangat lagi, maka pic pun dengan sengaja mengarahkan tubuhnya kearah peluru, sehingga dia tertembak, ito pun kaget dikarenakan pic tertembak dan itopun merasa senang dan bersemangat kembali dan melempar-lemparkan pic ke udara dan akhirnya mereka berdua bersahabat kembali.

\section{Pergerakan perframeln}

Penggunaan frame dalam animasi 3D serial ini menggunakan 25 frame per detik, total ukuran memori dari 25 frame perdetik ini tidak sama pada setiap scene nya, karena setiap scene memiliki kepadatan frame yang berbeda dan setiap scenenya ada yang tidak terdapat item ada pula memiliki tambahantambahan item, seperti adanya senjata, roket dan yang lainnya. sehingga setiap scenenya memiliki ukuran memory yang berbeda pula. Pada gambar 18 dan pada gambar 19. Di bawah ini dapat dilihat saat penggunaan dalam frame animasi . 


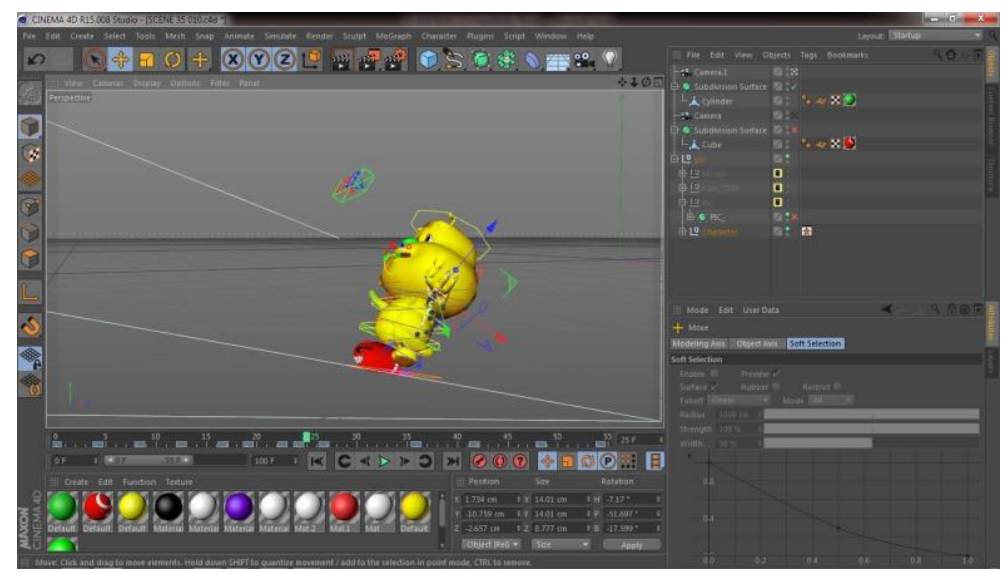

Gambar 18 Pic menaiki roket

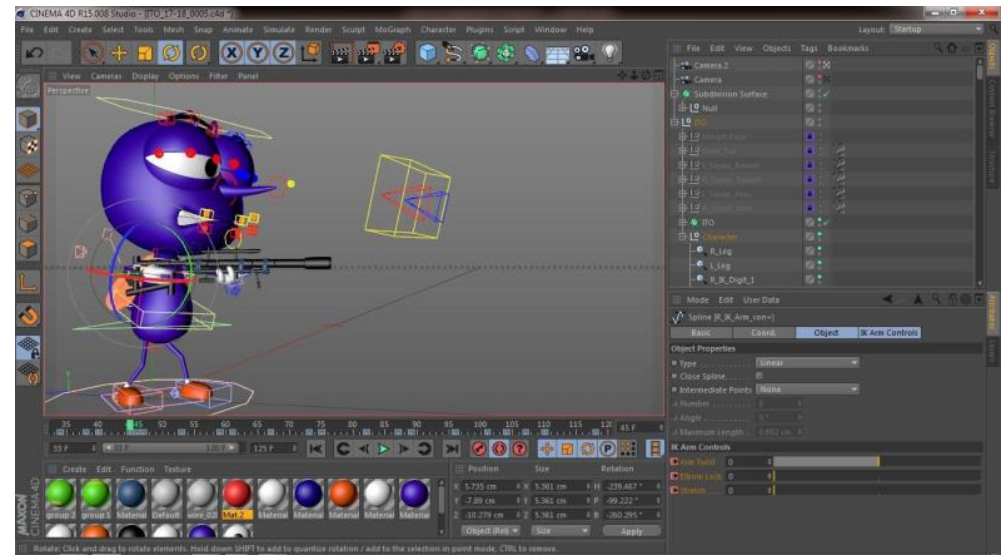

Gambar 19. ito dengan senjatanya

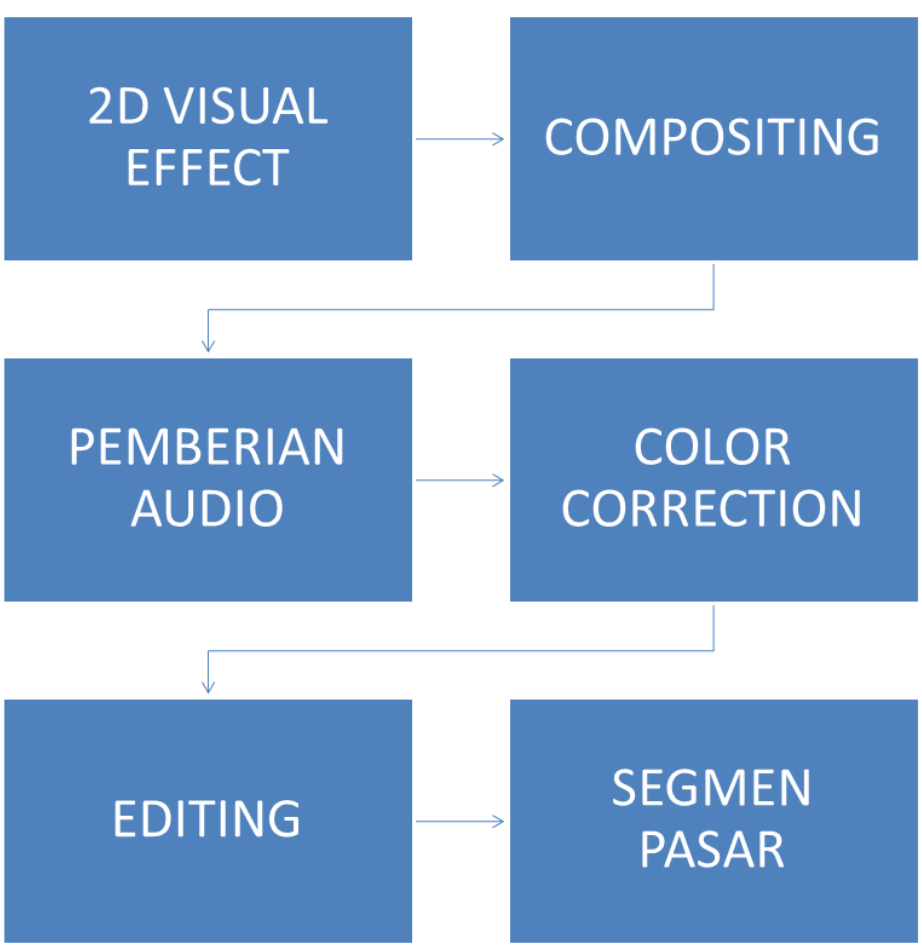

Gambar 20. Post Production 
Pada Gambar 20. dapat di lihat post production, post production ialah pasca produksi pada tahap akhir dalam pembuatan project. Proses post production yang pertama adalah pemberian 2D visual effect, kemudian compositing, pemberian audio, color correction, editing dan segmen pasar.

\section{KESIMPULAN}

Setelah melakukan penelitian pada PT. Movio Screen, kesimpulannya adalah bahwa media audio visual yang berupa film Animasi serial ini sangat di perlukan bagi PT. Movio Screen dan dengan adanya Media film Animasi serial tersebut Menjadi portofolio yang dapat menjadi penunjang promosi yang lebih baik untuk relasi dan calon konsumen PT. Movio Screen serta dapat meningkatkan citra dan asset bagi perusahaan. Target yang diharapkan oleh perusahaan melalui film animasi serial ini adalah agar semakin banyak yang menggunakan jasa industri kreatif pada PT. Movio Screen.

Dalam pembuatan Animasi serial yang baik, harus memperhatikan pergerkan character yang natural, character yang menjual dan cerita yang mengandung unsur moral. Dalam hal ini penulis menyesuaikan dengan keinginan stakeholder, seperti pembuatan cerita dan character. Hal ini bertujuan agar serial Animasi yang di buat lebih baik.

\section{DAFTAR PUSTAKA}

[1]. Anwar, Moh. Ali, Ardjaka, Sugiyono, Samodra, Joko. Fakultas Sastra Program Studi Desain Komunikasi Visual. Universitas Negeri Malang. Malang. 2012.

[2]. Arifin, zaenal. Evaluasi Pembelajaran: Prinsip, Teknik, Prosedur. Bandung: PT Remaja Rosdakarya. 2011

[3]. Destrianti, Dewi Immaniar, Sudaryono, Dwi Ayu Ningrum. Enriching Media Merchandise Sarana Penunjang Promosi Studi Kasus Pada Bookstore. Journal CCIT Vol. 7 No.3 - Mei 2014. Tangerang : Perguruan Tinggi Raharja, 2014.

[4]. Desrianti, Dewi Immaniar, Untung Rahardja, Reni Mulyani. Audio Visual As One Of The Teaching Resources On Ilearning. Journal CCIT Vol.5 No.2-Januari 2012. Tangerang: Perguruan Tinggi Raharja, 2012.

[5]. IDS / International Design School. Pengertian Animasi dan Jenis Animasi. Diakses pada 13 Juni 2014. Dari link http://www.idseducation.com/2014/06/13/apa-itu-animasi/

[6]. Jostonchoniv, Yudhi Windarto. Pembuatan Film Animasi 3D Cerita Rakyat “ Legend Of Toba Lake”. Fakultas Teknik dan Ilmu Komputer Jurusan Teknik Informatika Universitas Kristen Krida Wacana, Jakarta. 2013.

[7]. Milania. Pembuatan Film Animasi 3 Dimensi Berjudul "Impian Rahma" Menggunakan 3d Studio Max 7.0. Sekolah Tinggi Manajemen Informatika Dan Komputer Amikom. Yogyakarta. 2010.

[8]. Suratinoyo, Hendro Saputra, Wowor, Hans, Robot, Jimmy, Karouw, Stanley. Cerita Rakyat Daerah Minahasa : Implementasi Short Film Animas 3D. Teknik Informatika, Fakultas Teknik, Universitas Sam Ratulangi, Manado, 2013.

[9]. Wibawa, Cahya Budi. Pembuatan Film Animasi 3d Anak Berjudul “Ayo Kita Shalat”. Sekolah Tinggi Manajemen Informatika Dan Komputer Am 